\title{
Headmaster Strategies in Improving Teacher Competencies in the Digital Age
}

\author{
Hersigovina Putri ${ }^{1 *}$, Happy Fitria ${ }^{2}$, Yessi Fitriani ${ }^{2}$ \\ ${ }^{1}$ SMA Negeri 4 OKU, South of Sumatra, Indonesia \\ ${ }^{2}$ Universitas PGRI, Palembang, Indonesia \\ "Corresponding author. Email: hersigovina@gmail.com
}

\begin{abstract}
In an educational institution, the Principal has a very significant role to play in the back and forth of an educational institution, since the Principal plays a very important role in the growth of an educational institution. The role of school principals in enhancing teacher competence is very critical, since it can have an effect on the progress or lack of quality of education in the school itself. In the meantime, there are still some teachers in schools who still do not have the full potential to carry out their teaching skills, such as occasionally going to class, arriving late, and lazy to teach. There is always an "empty class" during active teaching hours. There are several challenges faced by teachers. Researchers are also involved in conducting research under the title Principal Strategy to Improve Teacher Competence in the Digital Age. The analysis uses a qualitative approach. Steps in the leadership strategy of the Principal in improving the professional competence of teachers in the digital age are divided into two strategic practices, formal and informal.
\end{abstract}

Keywords: Principal Strategy, Teacher Competence, Digital Age

\section{INTRODUCTION}

Through an academic facility, the Principal has a very significant role to play in the back and forth of an educational institution, since the Principal plays a very important role in the growth of an educational institution. The educational process is a public process [1]. One way to do this is by increasing the skill of the teacher. In an attempt to strengthen the performance of the teacher, the principal must be informed of all the improvements and innovations that have taken place in the school/institution. The principal has the authority and policies to increase the standard of education as a leader [2]. The existence of skilled and unprofessional teaching staff in an attempt to enhance the competence of teachers will have an influence on the teaching and learning process, because they must be able to achieve educational goals and also produce students who are capable of mastering science and technology and who have the confidence and fear of Allah SWT. Therefore, the concept is required to continuously improve the efficacy of science and technology. The principal as the backbone of the standard of education needs to serve as an energizer, advocate, pioneer and improve as well as an administrator.In other words, it is the guiding force behind the introduction of quality education management, including the quality of teachers and the quality of the learning process itself. The teacher really decides the progress of the learning process and the development of great quality students.

The teacher is becoming a subject of learning for students. As a topic of learning, the teacher has a job that is directly related to the students. While learning goals are those of students who are evolving individuals. The ability and competence of teachers to monitor classroom learning is therefore very significant. "Teaching is not only conveying subject matter, but is a work that is purposeful and complex in nature. The teacher's job is to prepare a generation of people who can live and play an active role in society" [3]. Kartini et al. [4]state that there is a substantial impact on the performance of teachers between principal leadership, instructional supervision and professional competence at the same time.

Through order to be able to carry out tasks properly in accordance with their field of expertise, an acceptable degree of expertise is necessary. To be a teacher is not only sufficient to understand the content that needs to be taught, but it also includes the capacity and 
comprehension of other expertise and skills, such as understanding the psychology of human development, understanding behaviors to alter theories, ability to plan and use media and learning tools, ability to design learning methods, assessment and learning. In order to accomplish the goals of learning, at least teachers must have basic teaching skills. Successful teachers can also produce high-quality students [5]. Teachers' basic teaching skills are needed so that teachers can play their part in managing the learning process, so that they can learn effectively and efficiently. In addition, basic skills are an absolute prerequisite for teachers to be able to incorporate different techniques. However, there are still many instances in the field of education where there are still many teachers who have difficulties in carrying out their duties. As a result, students are not able to absorb what the instructor says, and learning that is structured does not achieve its objectives.Education is a very important human need, because education has a responsibility to prepare human capital for the growth and advancement of the country[6].

Expertise is a competence that must be learned by teachers in order to carry out their key teaching tasks[7]. Developing the professional competence of teachers is a mechanism for reviewing, upgrading and expanding expertise, skills, attitudes and customs, both individually and in groups, so that all kinds of potential needs can be followed and evaluated on a regular basis and in compliance with the plan and deliver results for themselves and for the world of education [8].

Based on the above description, researchers are interested in conducting research under the title of the Principal Strategy to Increase Teacher Competence in the Digital Age. In this case, the researcher wants to find out how the actual strategy implemented by the Principal as a leader in improving the competence of SMA N 4 OKU teachers in the digital age is designed to ensure that the learning process can run smoothly and in line with the objectives to be achieved.

\section{METHODS}

This analysis uses qualitative approaches with a descriptive approach. In qualitative analysis, the data obtained are not statistics, but in the form of words or explanations. The data in question comes from interviews, field notes, photographs, personal records, etc [9].

In this report, the researchers identify in a detailed way the strategies implemented by the Principal at SMAN 4 Ogan Komering Ulu in increasing teacher competence, describing the circumstances that emerge in the research that raises the issue of the strategy implemented by the Principal.

The primary source of data which is the source of knowledge for this analysis is the main
source.Researchers need to use data collection methods, such as observation, interviews and documentation, to obtain the data required in this report. Since this study is in the form of descriptive qualitative research, the necessary data must be in the form of words, notes/writings, recordings, photographs, and others.

\section{RESULTS AND DISCUSSION}

\section{Formal Methods}

\section{a) Course and education}

The strategy adopted by the Principal of SMA Negeri 4 OKU in establishing professional competence of teachers and enhancing professional competence of teachers is often to conduct exchanges, including courses and training. Training can be carried out from hours to months, depending on the needs and wishes. Training can also be carried out with materials according to needs or wishes, so that almost all educational roles in schools can be trained: management, leadership, teaching and learning processes, administration, etc.

Teachers' main task is to teach, but there is nothing wrong with increasing knowledge and professionalism, and they also need to be prepared with the ability to learn and write articles/books. Because of the versatility of education and training in almost all aspects, training is often used as a way out of the SMA Negeri 4 OKU teaching quality issue. The note that needs to be disclosed so that education and training will really be a solution to teacher quality issues is that the application of education and training should be compatible with the objective.

\section{b) Seminar}

A seminar typically focuses on a single subject that can be actively engaged in by those who attend. Seminars are also performed through a conversation with a seminar instructor or through a more structured presentation of the results of the study. Seminar forums organized by and for teachers can be a successful way of communicating different subjects relevant to the field of science and the career as a teacher.

The seminars at SMA Negeri 4 OKU were held by two people who have always given inspiration to other teachers, namely Mrs. Hj. Jumiati, S.Pd MM as Principal of the School of Trusted Citizens, in this case it was handed over to Mrs. Mukhtamira, S.Pd Si M.Pd (Waka Curriculum), and together she encouraged the other teachers. In enhancing the professional competence of teachers, the Principal encourages teachers to be imaginative and inventive by making a variety of approaches to teachers and staff, in particular teachers in SMA Negeri 4 OKU. 


\section{c) MGMP Program (Subject Teacher Deliberation)}

In SMA Negeri $4 \mathrm{OKU}$, teachers are expected to attend the MGMP, a teacher organization founded to become a contact forum aimed at solving the problems faced by teachers in carrying out their daily work in the sector. The teacher is very grateful to the Principal for this work. So, if you're going to teach you don't rush and you can master the material.

\section{Non-formal Methods}

\section{a) Discipline:}

SMA Negeri 4 OKU still prioritizes discipline for students and teachers alike. Discipline began with Mrs. Hj Jumiati, S.Pd, M.M.M., who served as Principal of the School. Discipline is not only targeted at students but also at teachers who need to develop their discipline, since teachers are models for their students.

In order to ensure that order is maintained and that activities are carried out smoothly in order to achieve school objectives, it is important to have teachers who are full of loyalty and adherence to the relevant regulations and who are mindful of their responsibilities for the achievement of school objectives. In other words, the professionalism of teachers is very important in order to improve school objectives. Strengthening discipline is very important, and through discipline it can be seen how well the instructor can follow the laws. The teaching discipline of the teacher will ensure that the learning process is carried out efficiently and effectively.

\section{b) Motivate students, please}

Improving the professional competence of teachers includes the motivation and support of the different stakeholders, as well as the motivation of the principal. With this encouragement on the part of the Principal, the teacher is ready to carry out his duties. In addition, teachers are expected to draw up a quality activity plan in the short term, i.e. one year, after which the principal can make it happen.

Teachers are required to create motivation for learning, curiosity and a deep interest in the participation and active participation of students in school classes. And the more people who are strongly inspired to learn, the higher their learning achievement. Encouragement or inspiration not only comes from the Principal, but also motivates all teachers to develop and enhance their professional competence.

\section{CONCLUSION}

Steps for the Principal Leadership Strategy in the growth of the professional competence of teachers in SMA Negeri 4 OKU are divided into two strategic practices, the first being a structured strategy, that is to say, teachers are appointed by the institution to engage in education and training, both by the school institution itself and by the educational/training institutions, since they are currently underway. And non-formal methods, i.e. teachers on their own wishes and attempts to train and improve themselves relevant to work for their positions, such as: discipline, debate and encouragement.There are many barriers to the growth of the professional competence of teachers at SMA Negeri 4 OKU, among others: lack or restricted mastery of IT in schools and limited time, lack of imagination of teachers in the classroom learning process and inadequate selection of books or school facilities, and lack of scientific work by teachers.

\section{AUTHORS' CONTRIBUTION}

Hersigovina Putri: designed and performed experiments and analysed data. Happy Fitria and Yessi Fitriani: Performed analyses and supervised the research and co-wrote the paper.

\section{ACKNOWLEDGMENTS}

Our deepest gratitude goes to Teachers in SMA Negeri 4 OKU, Chancellor of Palembang PGRI University, Director of the Postgraduate Program of PGRI Palembang University and the Education Management Study Program of PGRI Palembang University, who have supported us in doing this extraordinary thing. This project is funded independently. We also want to thank our Education Management friends who helped us a lot in a short time frame to complete this project.

\section{REFERENCES}

[1] Maseleno, A., Ayshwary, B., Ivanova, T. N., Hashim, W., Nguyen, P. T., Shankar, K., Kristiawan, M., Huda, M. (2019). General Theoretical and Philosophical Aspects of Modern Education. Aspectos Teóricos y Filosóficos Generales de la Educación Moderna. Revista San Gregorio 2019, No. 32 Special Issues August.

[2] Asvio, N., Yamin, M., \& Risnita. (2019). Influence of Leadership Style, Emotional Intelligence and Job Satisfaction toward Organizational Commitment (Survey at SMA Muhammadiyah South Sumatera). International Journal of Scientific \& Technology Research 8 (8).

[3] Sanjaya, W. (2007). Strategi Pembelajaran Berorientasi Standar Proses Pendidikan [Standard-Oriented Learning Strategy Education Process]. Jakarta: Kencana.

[4] Kartini, D., Kristiawan, M., \& Fitria, H. (2020). The Influence of Principal's Leadership, Academic Supervision, and Professional Competence toward 
Teachers' Performance. Education and Training for Strengthening Principal to Effective Schools. International Journal of Progressive Sciences and Technologies (IJPSAT), 20(1).

[5] Hanim, H., \& Rahmadoni, J. (2020). Determination of Lecturer Reception Using Analytical Hierarchy Process (AHP). Journal of Applied Engineering and Technological Science (JAETS), 1 (2), 136141.

[6] Handayani, D. O., Kristiawan, M., \& Destiniar. (2020). Education and Training for Strengthening Principal to Effective Schools. International Journal of Progressive Sciences and Technologies (IJPSAT), 22(1), 321-326.

[7] Sagala, S. (2009). Kemampuan Profesional dan Guru dan Tenaga Kependidikan [Professional Ability and Teachers and Education Personnel] Bandung: Alfabeta.

[8] Edi, H.,Houtman.,\& Comalasari, E. (2020). Pengaruh Gaya Kepemimpinan Kepala Sekolah, Kompetensi Guru dan Manajemen Kelas terhadap Mutu Pembelajaran [The Effect of Principal Leadership Style, Teacher Competence and Classroom Management on Learning Quality]. Journal of Innovation in Teaching and Instructional Media. 1(1): 74-84.

[10] Usman, M. U. (2008).Menjadi Guru Profesional [Becoming a Professional Teacher].Bandung: PT. Remaja Rosdakarya. 